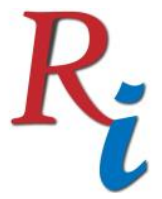

Asia Proceedings of Social Sciences

(APSS)

www.readersinsight.net/APSS

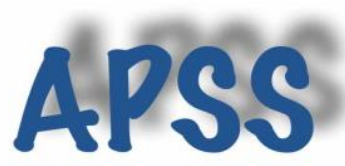

\title{
THE ROLE OF INSURANCE IN PROMOTING NATIONAL DEVELOPMENT
}

\section{Raji Sarafa Adebayo*}

Department of Insurance, School of Business and Management Studies Federal Polytechnic Offa.

Nigeria

*Corrosponding author's Email: rajisarafa94@yahoo.com

Author's Biography

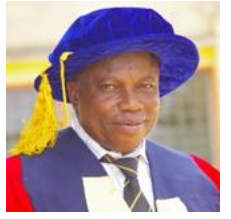

Raji Sarafa Adebayo has a B.Sc (Hons) in Insurance from University of Lagos in 1989, Masters in Business Administraton in 1996 and M.Sc in Management Science in 2006 both from University of Ilroin, Kwara State, Nigeria and capped it with Ph.D in Management Science from Ladoke Akintola University of Technology, Ogbomosho, Nigeria in 2013 specializing in Applied Management Science.

He is an associate, chartered insurance institute of nigeri by examination and a Fellow of Institute of operations Research (FIOR). He had about a decade in Insurancee Industry at both Gateway Insurance P.L.C and Metropolitan Trust Insurance PLC, Lagos. Currently, he is the director, Academic Planning Unit, Federal Polytechnic Offa, having headed various position in the past. He is an erudite and prolific writer. His research interest include Health Sector Planning, Insurance underwriting, Marketing, Educational Planning and Management.

Peer-review under responsibility of $3^{\text {rd }}$ Asia International Multidisciplanry Conference 2019 editorial board (http://www.utm.my/asia/our-team/) (C) 2019 Published by Readers Insight Publisher, lat 306 Savoy Residencia, Block 3 F11/1,44000 Islamabad. Pakistan, info@readersinsight.net This is an open access article under the CC BY-NC-ND license (http://creativecommons.org/licenses/by-nc-nd/4.0/). 


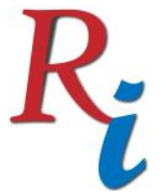

\section{Asia Proceedings of Social Sciences}

(APSS)

www.readersinsight.net/APSS

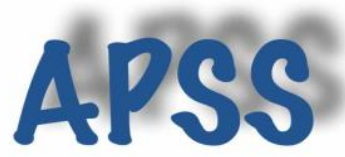

\section{Rese a r ch H i g h I igh t s}

Development as a concept has attracted definitions by scholars based on their peception of it; since it does not lend itself to a universal definition. Hence in Gboyega (2003), development was decribed as an idea that embodies all attempts to improve the conditions of human existence in all ramifications. This implies that there must be improvement in material well being of all citizens, not the most powerful and rich alone, in a sustainable way such that todays consumption does not imperil the future it also demands that poverty and inequality of access to the good things of life be removed or drastically reduced.

Further development on national basis is imperative to the sustanence and growth of a nation.

\section{Research Objectives}

The objective of the paper is to assess the role of insurance towards national development in Nigeria.

\section{Methodology}

The methodology adopted is mainly secondary source, hence, relevant materials were considered and opinion formed. The various development plans nigeria were considered, from the first Development Plan $(1962$ - 1968) to the most recent of National Industrial Revolution Plan of 2014. The experience of countries such as Malaysian, South-Korea, Australia and Japan among others as a guide for Nigeria. This paper also took a critical look at the role insurance play in National Development

\section{Results}

As stated in Oke (2012) and Shittu (2012) as cited in Momoh (2018) that insurance affect economic growth and National Development by providing protection for the insured through the channel of marginal productivity of capital, technological innovation and saving rate. Aslo, Okonjo-Iweala (2015) opined that the insurance industry is an important component of financial system of the country needed to drive economic development and industrialisation. That without the required insurance cover, all industrial, economic and social activities of the world will obviously come to a grinding halt.

This further corroborated in Khan (2014) that, insurance is a risk transfer mechanism, such that individual and business enterprise can shift some of the uncertainities of life on the shoulder of the other. That insurance provides protection for trade and industry. That such will lead to innovation and inventions which ultimately contribute to human progress, economic, social and technological progress. The above will avail the industry the oppurtunity to look for new and more high-tech machines, robots and gadgets, atomic technology and other sophisticated mordern equipment that will boost manufacturing and production activities of the economy which will ultimately engender the much desired national development for the country. Also in Momoh (2018), it was reported that the importance of the insurance sub-sector cannot be over emphasized, because the success of other sectors depends on the insurance industry. Ege and Savac (2011) conducted a study on the role of insurance in economic growth hence national development of 29 countries. The study adopted fixed effect models for the period of 1999-2008. The sudy finds that insurance investment affects economic growth and national development significantly and positively. 


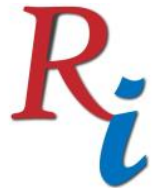

\section{Asia Proceedings of Social Sciences (APSS) \\ www.readersinsight.net/APSS}

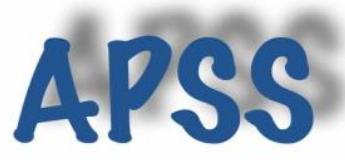

\section{Findings}

The critical role of insurance to boost national development includes; offering insurance and financial protection, instilling sense of security and peace of mind, acting as stabilizing factor, acting as institutional investor, public safety and new product development. The other roles includes; enhancing financial security and peace of mind among others. It was further stated that for insurance to function effectively in this role, the government and other stakeholders must rise to the emerging challenges suggestion for improvement was made to which includes that government must develop and support improvements of policies that engender national development, training institutions, parent and guardian, development partners and employers as stakeholders must be ready to be proactive to enthrown a sustainable national development as obtained in the developed world.

\section{Acknowledgement}

I acknowledge the contributions of Mr. Noah G. Alli of Insurance Department, Federal Polytechnic Offa to ensure the manuscript see the light of the day. Also, the effort of Raji Abdul Malik Ajbola and Mr. Hammed a doctoral candidate of UPM, Malaysia. Thank you all.

\section{References}

Federal Government of Nigeria (1981). National policy on education. Federal Government Press Limited, Lagos

Gboyega A, (2003). Democracy and development: the imperative of local governance. An Inaugural Lecture, University of Ibadan, pp 6-7.

Iwaela N.O (2015). Insurance news, the nation newspaper, Vintage Press limited, Lagos. pp 35 - 38.

Khan Z.A (2014). Importance of Insurance in our economy, Articles, Features \& Review, Google, pp 18-19

Momoh, Omowumi (2018). Impact of the Nigerian insurance industry on sustainable economic growth and development. International Journal of Management and Social Science Research (IJMSSR). Vol. 7(4).

Raji S.A, et. al., (2013). Insurance textbook for senior secondary school in Nigeria. Chartered Insurance Institute of Nigeria (CIIN) Lagos. Pp $2-55$ 